\title{
Pengalaman Vietnam Melakukan Transplantasi Hukum: Persaingan Terhadap Kondisi Domestik Setempat
}

\author{
Isharyanto \\ Fakultas Hukum Universitas Sebelas Maret Surakarta \\ Jln. Ir. Sutarmi No. 36 A Pucangsawit Jebres Surakarta \\ isharyanto_fh@staff.uns.ac.id
}

Received: 25 Januari 2020; Accepted: 17 Februari 2020; Published: 29 Juni 2020

DOI: 10.20885/iustum.vol27.iss1.art3

\begin{abstract}
This paper describes the problems and challenges as the effects of legal transplantation. As a policy alternative, legal transplantation is an appropriate short-term solution to immediately produce a new legal formulation. This study focuses on analyzing the characters of legal transplant in Vietnam which reflects the competition in local domestic conditions. This doctrinal legal research uses both conceptual and historical approach. The conceptual approach refers to the issue of legal transplantation while the historical approach refers to the historical course of law in Vietnam. Conclusively, in Vietnam's experience, the results of a legal transplant did not take place smoothly and immediately. The footprint of the legal transition and the combination of traditional order with the influence of colonial inheritance law causes the transplantation effect to not immediately contribute to positive conditions for legal development. Apart from the rigid communist system, which accommodates a market-friendly liberal economic system, the need for regulation in accordance with the development of contemporary social relations arises. However, party interference, including in controlling judges and courts, causes mixed forms of legal transplantation that have no equivalent in the mainstream legal system. Transplanted law in Vietnam does not only present a new face to the law and court system, but also influences the challenges of future development so that the transplantation effect can contribute to positive steps for legal reform.
\end{abstract}

Keywords: Legal reform; legal transplant; legal transition; Vietnam

\section{Abstrak}

Tulisan ini mendeskripsikan persoalan dan tantangan sebagai efek transplantasi hukum. Sebagai pilihan kebijakan, transplantasi hukum merupakan solusi jangka pendek yang tepat untuk segera menghasilkan formulasi hukum baru. Tulisan ini fokus menganalisis karakter transplantasi hukum di Vietnam yang mencerminkan persaingan kondisi domestik setempat. Penelitian hukum doktrinal ini menggunakan pendekatan konseptual dan historis. Pendekatan konseptual dihubungkan dengan isu transplantasi hukum dan pendekatan historis dihubungkan dengan perjalanan sejarah hukum di Vietnam. Sebagai kesimpulan, dalam pengalaman Vietnam, hasil transplantasi hukum tidak segera terjadi dengan mulus. Jejak transisi hukum dan paduan tatanan tradisional dengan pengaruh hukum warisan kolonial menyebabkan efek transplantasi tidak segera menyumbang kondisi positif bagi pembangunan hukum. Lepas dari sistem komunis yang kaku, yang mengakomodasi sistem ekonomi liberal yang ramah pasar, kebutuhan regulasi yang sesuai dengan perkembangan relasi sosial kontemporer timbul. Tetapi, campur tangan partai, termasuk dalam mengendalikan hakim dan pengadilan, menyebabkan bentuk transplantasi hukum campuran yang tidak memiliki padanan dalam sistem hukum arus utama. Transplantasi hukum di Vietnam bukan saja menampilkan wajah baru sistem undang-undang dan pengadilan, namun juga berpengaruh ke tantangan pengembangan pada masa depan supaya efek transplantasi dapat menyumbangkan langkah positif pembaruan hukum.

Kata-kata Kunci: Pembaruan hukum; transplantasi hukum; transisi hukum; Vietnam 


\section{Pendahuluan}

Alan Watson terkenal dengan karya tulis yang mendefinisikan transplantasi hukum sebagai "perpindahan satu aturan atau sistem hukum dari satu negara ke negara lain" atau "pemindahan orang dari satu negara ke negara lain"1 Watson tentu bukan orang pertama yang memperkenalkan istilah itu, akan tetapi definisi yang dianjurkan tersebut menjadi terkenal. Sudah barang tentu ada penolakan di antara komunitas akademik, ${ }^{2}$ namun harus diakui bahwa sajian pemahaman yang dibangun Watson acap kali menjadi rujukan bagi pelaksana kebijakan dan pembentuk undang-undang saat melakukan pembaruan hukum, juga untuk membaca pengaruh asing dalam sebuah sistem hukum nasional. ${ }^{3}$

Pemahaman Watson tersebut, harus diakui, memiliki keterbatasan dan terlalu membatasi, karena tak cukup dapat digunakan untuk menjelaskan dan memberikan analisis terhadap fenomena modern. Sejumlah keterbatasan telah diidentifikasi dan dianalisis. Sebagai contoh, pandangan Watson hanya cocok untuk fenomena hukum perdata. ${ }^{4}$ Keberatan lain terhadap teorisasi Watson adalah sehubungan dengan sejarah hukum. ${ }^{5}$ Demikian pula, persoalan tranplantasi hukum telah menjadi perdebatan terus-menerus di kalangan pemerhati perbandingan hukum, dengan sudut pandang yang satu sama lain saling bertentangan. Legrand, penentang terkemuka tranplantasi hukum, pernah mengatakan, "at best, what can be displaced from one jurisdiction to another is, literally, a meaningless form of words."6

Pada sisi lain, Watson, yang dianggap bapak transplantasi hukum, yang mengabdikan pengetahuan sepenuhnya untuk kajian ini mengatakan, "legal transplants are alive and well as they were in the time of Hammurabi."7 Lebih lanjut,

\footnotetext{
1 Alan Watson, "The Birth of Legal Transplants," Georgia Journal of International and Comparative Law , Vol.41, 2013, hlm. 605.

2 Frances H. Foster, “American Trust Law in a Chinese Mirror,” Minnesota Law Review, Vol. 94, 2010, hlm. 602.

${ }^{3}$ Lihat, Michael H.K. Ng, Legal Transplantation in Early Twentieth-Century China: Practicing Law in Republican Beijing (1910s-1930s), Routledge, London, 2014.

${ }^{4}$ Catherine Dupré, Importing the Law in Post-Communist Transitions: The Hungarian Constitutional Court and the Right to Human Dignity, Bloomsbury Publishing, London, 2003, hlm. 40-41.

${ }^{5}$ Ibid., hlm. 40.

${ }^{6}$ Pierre Legrand, "What Legal Transplant?," dalam David Nelken, Johannes Feest (ed.), Adopting Legal Cultures, Hart Publishing, London, 2001, hlm. 63.

7 Alan Watson, Legal Transplants: An Approach to Comparative Law, University of Georgia Press, Athens, 1993, hlm. 12.
} 
Watson berujar, "indeed, I believe I have indicated, though by example rather than by express statement, that borrowing is usually the major factor in legal change."8

Kedaulatan negara-negara modern sering mendorong mereka untuk melaksanakan pembaruan dan resepsi hukum. ${ }^{9}$ Negara-negara ini telah mempertimbangkan solusi pilihan dan kombinasi menurut bermacam-macam sistem asing yang dipercaya sebagai pemecahan terbaik dalam mengatasi persoalan mereka. Di negara-negara pasca komunis seperti Vietnam, solusi itu berserakan dan bersifat multidimensional. ${ }^{10}$ Negara-negara ini melakukan banyak pertimbangan atas sistem-sistem asing, kemudian mengambil salah satu atau menggabungkan satu sama lain supaya menghasilkan formula yang cocok bagi kepentingan domestik mereka. Praktik demikian tadi memberikan sumbangan bentuk tranplantasi hukum baru di era modern.

Bentuk transplantasi hukum yang baru ini yang akan menjadi fokus dalam tulisan ini. Negara Vietnam dijadikan studi sepenuhnya. Dalam proses transplantasi, Vietnam telah mereformasi tidak hanya hukum privat, tetapi juga sebagian besar hukum publiknya. Dalam konteks ini, Vietnam menonjol sebagai contoh utama dari negara sosialis dalam masa transisi yang secara aktif berupaya mereformasi sistem hukum dengan menggabungkan berbagai transplantasi hukum guna dapat menciptakan solusi yang paling cocok, layak, dan dapat diterapkan dalam pembangunan hukum negara. Sejak implementasi kebijakan Doi Moi (Pembaruan) pada akhir 1986, Vietnam telah menjalankan program reformasi hukum agresif dengan tujuan mengubah negara dari kediktatoran proletariat dengan ekonomi terencana menjadi negara berbasis rule of law yang ramah pasar.11 Sebagian besar reformasi ini terjadi di bawah pengaruh transplantasi hukum yang bersifat campuran. Dalam hal ini, anggota parlemen dengan hati-hati mempertimbangkan aturan dan model asing, dan kemudian mencampurkan berbagai solusi yang ditemukan dalam sumber-sumber asing

\footnotetext{
${ }^{8}$ Ibid., Bab 6.

${ }^{9}$ Lihat, John Stanley Gillespie, Transplanting Commercial Law Reform: Developing a Rule of Law' in Vietnam, Ashgate Publishing Ltd, London, 2006.

${ }^{10}$ Baca, John Gillespie dan Pip Nicholson (ed.), Law and Development and the Global Discourses of Legal Transfers, Cambridge University Press, London, 2012.

${ }^{11}$ Pham Van Thuyet, "Vietnam's Legal Framework for Foreign Investment," The International Lanyer, Vol. 33, No. 3, 1999, hlm. 765-99.
} 
tersebut untuk menciptakan formulasi hukum baru, sesuatu yang terkadang membawa masalah struktural dan mengancam menggagalkan reformasi. ${ }^{12}$ Vietnam, seperti negara-negara bekas Uni Soviet dan Eropa Timur, menghadapi tantangan ketika bergerak ke arah ekonomi yang beragam dan jauh dari struktur yang diinspirasikan oleh Soviet, yang direncanakan secara terpusat. Seluruh sektor ekonomi telah dan terus menjalani privatisasi; kontrol harga telah dicabut pada sebagian besar komoditas; lahan pertanian didekolektivisasi dan kemudian diprivatisasi atau diserahkan kepada petani dengan sewa jangka panjang; dan bisnis swasta berkembang pesat di Vietnam wilayah selatan dan memulai ekspansi cepat di Vietnam di bagian utara dan tengah.

\section{Rumusan Masalah}

Berdasarkan latar belakang di atas, diajukan rumusan masalah sebagai berikut: bagaimana karakter transplantasi hukum di Vietnam yang mencerminkan persaingan dengan kondisi domestik setempat?

\section{Tujuan Penelitian}

Tujuan penulisan artikel ini adalah untuk memberi analisis tentang karakter transplantasi hukum di Vietnam yang mencerminkan negosiasi ruang dan waktu domestik.

\section{Metode Penelitian}

Artikel ini merupakan hasil dari penelitian hukum doktrinal. Sebagaimana diketahui, penelitian hukum doktrinal merupakan penelitian-penelitian atas hukum yang dikonsepkan dan dikembangkan atas dasar doktrin yang dianut sang pengkonsep dan/atau sang pengembangnya. Sumber informasi penelitian bertumpu pada bahan hukum sekunder, yang meliputi bahan kepustakaan berupa artikel jurnal dan laporan-laporan resmi sehubungan dengan isu penelitian. Pendekatan penelitian dilakukan melalui pendekatan konseptual dan historis. Pendekatan konsep ditimpakan sehubungan dengan peta pemahaman mengenai isu transplantasi hukum dan pendekatan historis dihubungkan dengan perjalanan sejarah hukum di Vietnam sesuai dengan isu penelitian.

12 Carlyle A Thayer, "Force Modernization: Vietnam," Southeast Asian Affairs, 2018, hlm. 429-44. 


\section{Hasil Penelitian dan Pembahasan}

\section{Perkembangan Sistem Hukum dan Kebutuhan Reformasi}

Istilah transplantasi hukum, peminjaman hukum (legal borrowing), dan penerimaan hukum (legal reseption) biasanya digunakan untuk menjelaskan fenomena serupa, yaitu difusi model hukum satu negara terhadap negara lain. Secara lebih luas, ketiga istilah tadi merujuk proyek reformasi hukum yang diprakarsai oleh proyek perubahan hukum dalam hal peniruan hukum, doktrin, atau putusan pengadilan dalam berbagai sistem hukum. ${ }^{13}$ Namun, tulisan ini berpandangan bahwa terutama konsep peminjaman hukum dan transplantasi hukum tidak serta merta memiliki kesamaan. Sebuah transplantasi hukum harus dihubungkan dengan pernyataan "that 'the law' or 'the rules of the law' travel across jurisdictions must have in mind that law is a somewhat autonomous entity unencumbered by historical, epistemological, or cultural baggage. Indeed, how could law travel if it was not segregated from society ${ }^{14}$

Sebelum 1864, sistem hukum Vietnam berwatak khas Asia Timur, dengan kepala negara atau raja sebagai sumber konsentrasi kekuasaan dalam bidang eksekutif, legislatif, dan yudisial. Kodifikasi undang-undang, yang disahkan raja, permanen dan kaku. Padahal, ketika terjadi perubahan masyarakat, undangundang yang ada tak mampu mengikuti hal-hal baru yang terjadi. Untuk menghadapi persoalan ini, dengan kuasa raja, dibangun sistem yurisprudensi. Putusan-putusan raja, yang juga sebagai pemegang kuasa yudisial, dalam menyelesaikan perkara-perkara yang identik ditujukan pula untuk perkaraperkara yang terjadi pada masa berikutnya. Artinya, lahirlah dalil-dalil umum dalam menafsirkan undang-undang yang berlaku. Sayangnya, yurisprudensi tetap tak terbangun, minimal dengan dua alasan. Pertama, para hakim enggan berpaling dari undang-undang. Kedua, dalam perkara pidana, mekanisme penjatuhan sanksi tidak bisa mengubah ketentuan undang-undang. ${ }^{15}$

\footnotetext{
${ }_{13}$ David S. Clark, Encyclopedia of law \& society: American and global perspectives (Vols. 1-3), Thousand Oaks, CA: Sage Publications, 2007.

14 Pierre Legrand, "The Impossibility of 'Legal Transplants", Maastricht Journal of European and Comparative Law, 4, 1997, hlm. 112-124.

${ }^{15}$ Lihat, Giang Chau, "Trade to Firm up After Solid Promotion During First Year," Vietnam Investment Review, 10, No. 1, 2003.
} 
Penjajahan Perancis pada 1864-1954 mengubah wajah hukum Vietnam. Watak sistem hukum sipil mengemuka. Ada tatanan baru yang diimpor dari peradaban Barat. ${ }^{16}$ Perancis, dengan semangat tata pemerintahan baru, memberlakukan kodifikasi hukum secara beragam. Namun demikian, ketiga kodifikasi itu memiliki karakter serupa, yaitu menampilkan wajah warisan kodifikasi Napoleon 1804. Sebagai konsekuensi, rintisan pembangunan yurisprudensi juga mendapat tempat menurut pola Perancis ini. Sistem Perancis tidak cocok berkaitan dengan tradisi hukum Vietnam dan tak mampu menyelesaikan perkara-perkara berdasarkan keanekaragamaan hukum lokal.

Oleh sebab itu, para hakim harus melengkapi undang-undang dengan mencari prinsip-prinsip hukum umum. Bahkan, sistem peradilan adat menjadi bagian dari sistem hukum Perancis, dengan Mahkamah Agung di Paris sebagai puncak peradilan. Para hakim Vietnam, dengan demikian, juga memeroleh pengaruh prestisius dari para hakim Perancis. Hal ini memberikan ciri khas terhadap bangunan yurisprudensi khas selama periode penjajahan Perancis. Banyak di antara putusan-putusan hakim kemudian dicatat dan dikompilasi. Bahkan, terdapat pula anotasi terhadap putusan-putusan pengadilan dalam rentang waktu 1898-1899. Dengan pengaruh kuat dari Perancis, yurisprudensi di Vietnam saat itu memiliki kedudukan serupa dengan negara penjajah itu, yaitu melengkapi kitab undang-undang dan undang-undang.

Watak hukum Perancis berlanjut dengan terbentuknya Vietnam Selatan pada masa republik. Kodifikasi hukum warisan kolonial dipertahankan. Yurisprudensi tidak terlalu mengikat, sebagaimana dipraktikkan di Perancis. Mahkamah Agung menjadi peradilan tertinggi, termasuk memandu dan memastikan keseragaman keberlakuan hukum. Dengan jatuhnya republik pada 1975, bangunan hukum seperti itu kemudian tidak dapat dipertahankan lagi. ${ }^{17}$

Dengan ideologi sosialisme, Vietnam Utara mempertahankan pula warisan Perancis. Yurisprudensi menjadi pilihan rasional. Hal ini karena rezim pemerintah menghapus keberlakuan kodifikasi warisan kolonial, akan tetapi

${ }^{16}$ Bui Xuan Hai dan Chihiro Nunoi, "Corporate Governance in Vietnam - A System in Transition," Hitotsubashi Journal of Commerce and Management, Vol. 42, 2008, hlm. 45.

17 Lihat, Le Hong Hiep, "Vietnam's Strategic Trajectory: From Internal Development to External Engagement”, Strategic Insights No. 59, Australian Strategic Policy Institute, 2012. 
tidak pernah menyusun peraturan baru. Pada 1959, Mahkamah Agung mengeluarkan instruksi, mencabut kodifikasi, dengan alasan untuk melenyapkan hukum yang berwatak feodal dan warisan kolonial. Para hakim kebingunangan untuk memutuskan perkara sebab undang-undang baru belum dibentuk. Dengan sebuah edaran Kementerian Kehakiman pada 11 November 1959, dianjurkan agar para hakim memperhatikan dan menggunakan yurisprudensi untuk memeriksa dan memutus perkara. Mahkamah Agung membiarkan hal itu, termasuk mendukung sikap pengadilan banding yang merujuk kepada yurisprudensi yang pernah ada. ${ }^{18}$

Pada 1975, Vietnam pasca perang mengadopsi model ekonomi Soviet melalui perencanaan pusat dan subsidi negara dalam skala yang lebih besar. Namun, pembangunan industri berat dan proyek-proyek berskala besar terbukti tidak efisien dan menghabiskan terlalu banyak investasi. ${ }^{19}$ Lebih penting lagi, tingginya kolektibilitas sektor pertanian mengubah petani menjadi pekerja industri. Ini memaksa Vietnam, sebagai negara agraris, untuk bergantung pada impor beras dan makanan lainnya. ${ }^{20}$ Pada pertengahan 1980-an, ekonomi Vietnam kehabisan bahan-bahan pokok; tingkat inflasi tahunan mencapai tiga digit dan kehidupan orang-orang menurun secara drastis. Situasi ekonomi Vietnam diperparah oleh masalah ekonomi Uni Soviet, yang secara tajam mengurangi bantuannya ke Vietnam. Vietnam memertahankan defisit anggaran yang besar dan utang luar negerinya meningkat. ${ }^{21}$

Pemerintah Vietnam menerapkan penyesuaian terbatas di sektor pertanian pada awal 1980-an dalam menghadapi inefisiensi ekonomi dan kekurangan pangan. Untuk menciptakan insentif bagi produksi pertanian, petani secara kolektif dikontrak untuk mencapai tingkat produksi tertentu dan menikmati

\footnotetext{
${ }^{18}$ Carlyle A Thayer, "Force Modernization...Loc.Cit.

${ }^{19}$ Buu Hoan, "Soviet Economic Aid to Vietnam," Contemporary Southeast Asia 12, No. 4, 1991, hlm. 360-76.

${ }^{20}$ N. Hoang, A.Toppinen, dan K. Lahtinen, "Foreign subsidiary development in the context of a global recession: a case of the furniture industry in Vietnam," The International Forestry Review 17, No. 4, 2015, hlm, 427-37.

21 Susanne Birgerson, "The Evolution of Soviet Foreign Policy in Southeast Asia: Implications for Russian Foreign Policy," Asian Affairs: An American Review 23, No. 4, 1997, hlm. 212-34.
} 
kelebihan produksi. Penyesuaian ini membantu meningkatkan produksi pertanian tanpa investasi baru. ${ }^{22}$

Pada awal-awal membangun negara berdasarkan sosialisme, rezim pemerintah memihak pada hukum Soviet sebagai model terbaik. Hukum publik dianggap lebih utama dibandingkan hukum perdata, sembari juga menolak pemilihan antara kedua jenis hukum tersebut. Hal ini tak mengherankan, mengingat watak negara kekuasaan yang lahir, diiringi sistem ekonomi yang terencana, membuat relasi-relasi sosial pun ditentukan oleh pemerintah. ${ }^{23}$

Lembaga pemerintah dengan tanggung jawab utama untuk urusan hukum, Kementerian Kehakiman, telah ditutup pada 1960-an sebagai bagian dari penghinaan terhadap proses hukum. Tugas-tugas yang tidak dihilangkan, seperti pendidikan hukum, diambil alih oleh otoritas keamanan internal, polisi, dan kelompok-kelompok Partai. Baru pada 1976, setelah Saigon jatuh, sebuah fakultas hukum kecil didirikan di Universitas Hanoi di bawah Kementerian Pendidikan dan Pelatihan. Beberapa tahun kemudian, upaya awal dilakukan untuk memperkuat fasilitas penelitian hukum utama, pendirian Institut Negara dan Hukum di Hanoi; pembentukan Sekolah Pelatihan Hakim oleh Mahkamah Agung Rakyat pada 1979; dan Komisi Hukum Negara (pendahulu Kementerian Kehakiman) membuka sekolah pelatihan hukum selama dua tahun. Berbagai kelembagaan ini kemudian digabung dalam Hanoi Law College. ${ }^{24}$

Fakultas Hukum Universitas Hanoi dan Sekolah Pelatihan Hakim, dalam suatu langkah yang menghambat pengembangan kelembagaan di kemudian hari, ditutup. Perguruan Tinggi Hukum Hanoi baru dibentuk, dan masih berkantor pusat, di bekas lokasi Sekolah Pelatihan Hakim di barat daya Hanoi. Ketika Departemen Kehakiman dibuka kembali secara resmi pada 1981, dua puluh tahun setelah dihapus, kendali atas Sekolah Tinggi Hukum Hanoi lalu diambil. Dalam beberapa tahun setelah pembukaan Hanoi Law College pada 1981, Kementerian Kehakiman membuka sekolah baru di Ho Chi Minh City. Pada akhir 1980-an,

\footnotetext{
22 Pedro Conceição dan Ronald U. Mendoza, “Anatomy of the Global Food Crisis," Third World Quarterly 30, No. 6, 2009, hlm. 1159-81.

${ }^{23}$ Mark Sidel, "The Re-Emergence of Legal Discourse in Vietnam," The International and Comparative Law Quarterly 43, No. 1, 1994, hlm. 163-74.

24 Pham Quang Minh, "Teaching international relations in Vietnam: chances and challenges," International Relations of the Asia-Pacific 9, No. 1, 2009, hlm. 131-55.
} 
ketika kebijakan Partai dan negara bergeser ke arah reformasi ekonomi, Universitas Hanoi dan Kementerian Pendidikan dan Pelatihan membentuk kembali fakultas hukum. ${ }^{25}$

Institusi pendidikan dan penelitian hukum Vietnam serta para sarjana hukum menghadapi kesulitan intelektual dan fisik untuk memenuhi berbagai beban berat; mengembangkan undang-undang yang konsisten secara internal untuk melayani proses reformasi ekonomi dan politik. Tekanan waktu yang serupa juga terlihat dalam pelatihan, pemberian saran, dan fungsi-fungsi lain yang berhadapan dengan fakultas hukum, serta pertimbangan reformasi hukum, ekonomi, dan politik yang lebih luas di mana para sarjana hukum Vietnam harus terlibat. ${ }^{26}$

Sistem ekonomi terencana dalam perkembangan berikutnya mulai dipertanyakan akibat krisisi ekonomi yang tak lekas pulih. Pada pertengahan 1980-an, meskipun ada beberapa penyesuaian ekonomi, ekonomi Vietnam tumbuh melambat. Bangunan industri berat gagal mengembangkan produksi, meningkatkan pasokan barang, atau memenuhi kebutuhan masyarakat. Sistem birokrasi secara terpusat menghambat akses pasar. ${ }^{27}$

Demikian pula, aktivitas bisnis swasta dibatasi. Di sektor pertanian, petani kurang memiliki minat pribadi dalam budidaya di bawah struktur kolektivisasi. Yang memperburuk keadaan, pasar gelap muncul dengan harga yang jauh lebih tinggi, menyerap pasokan barang yang sudah langka. Pada 1985, dalam upaya untuk mengatasi kenaikan inflasi, pemerintah merespons dengan menaikkan harga di sektor publik, meningkatkan upah, dan melakukan devaluasi. ${ }^{28}$

Pemerintah mulai tertarik menjalankan ekonomi pasar. ${ }^{29}$ Tentu saja, hukum model Soviet tidak relevan dengan rencana baru tersebut. ${ }^{30}$ Tradisi pengutamaan

\footnotetext{
${ }^{25}$ Carol V. Rose, “The 'New' Law and Development Movement in the Post-Cold War Era: A Vietnam Case Study," Law \& Society Review 31, No. 1, 1998, hlm. 93-140.

$26 \mathrm{Vu}$ Minh Khuong, "Can Vietnam Achieve More Robust Economic Growth? Insights from a Comparative Analysis of Economic Reforms in Vietnam and China," Journal of Southeast Asian Economies 321, No. 1, 2015, hlm. 52-83.

27 Adrian Wood, "Deceleration of inflation with acceleration of price reform: Vietnam's remarkable recent experience," Cambridge Journal of Economics 13, No. 4, 1989, hlm. 563-71.

${ }^{28}$ Ibid

29 Pham Van Duc dan Tran Tuan Phong, "The Views of Some Economic Theories on the Economic Crisis of Capitalism and Some Lessons for Vietnam," World Review of Political Economy, Vol.1, No. 4, 2010, hlm. 724-28.
} 
hukum publik mulai ditinjau lagi. Ini lantaran relasi sosial yang muncul karena liberalisasi ekonomi menuntut ketersedian hukum perdata, hukum dagang, dan hukum ketenagakerjaan, sesuatu yang dianggap penting menjadi bidang reformasi hukum. ${ }^{31}$ Pada 1986, dalam Kongres Partai Komunis ke-6, diluncurkan paket kebijakan pembaruan, Doi Moi. Paket kebijakan ini menuntut dua bidang pembaruan penting, yaitu sistem ekonomi nasional dan sistem hukum. ${ }^{32}$ Pemerintah memutar haluan guna melakukan adaptasi dengan relasi-relasi sosial yang ramah pasar. Jargon kodifikasi undang-undang dikumandangkan kembali. ${ }^{33}$ Serangkaian paket undang-undang kemudian diluncurkan dalam rangka pembaruan tadi: Undang-Undang Penanaman Modal (1987), Undang-Undang Perseroan (1990), Undang-Undang BUMN (1990), dan Kitab Undang-Undang Hukum Perdata (1995). ${ }^{34}$ Sayangnya, undang-undang tersebut terus-menerus direvisi dan sulit diidentifikasi perubahan-perubahannya mengingat tak pernah ada catatan resmi soal itu. Perubahan terus berjalan hampir sepuluh tahun kemudian. 35

Tetapi, "reformasi hukum" juga memiliki arti lain di Vietnam. Para pemimpin Partai Komunis didorong dalam ranah politik oleh dua dorongan yang berbeda dan terkadang saling bertentangan. Di satu sisi, pluralisme, diskusi yang lebih besar tentang isu-isu sosial, dan jangkauan yang lebih luas dari kebebasan pribadi harus mulai memasuki kehidupan sehari-hari warga Vietnam. Beberapa anggota kepemimpinan Partai mengakui peningkatan fleksibilitas dalam urusan pribadi dan politik sebagaimana diperlukan untuk mempromosikan diversifikasi ekonomi dan liberalisasi. Bagi yang lain, itu mungkin sesuatu dari tujuan itu

${ }^{30}$ Lihat, Pham Duy Nghia, "Confucianism and the Conception of the Law in Vietnam," dalam John Gillespie dan Pip Nicholson (Ed.), Asian Socialism and Legal Change: The Dynamics of Vietnamese and Chinese Reform, ANU Press, Canberrra, 2005.

${ }^{31}$ Lihat, Tannetje Bryant dan Brad Jessup, "Fragmented Pragmatism: The Conclusion and Adoption of International Treaties in Vietnam," dalam John Gillespie dan Pip Nicholson (Ed.), Asian Socialism and Legal Change: The Dynamics of Vietnamese and Chinese Reform, ANU Press, Canberrra, 2005.

32 Ronald J. Cima, "Vietnam's Economic Reform: Approaching the 1990s," Asian Survey, Vol.29, No.5, 1989, hlm. 786-99.

33 Mark Sidel, "The Re-Emergence of Legal Discourse in Vietnam," The International and Comparative Law Quarterly, Vol.43, No.1, 1994, hlm. 163-74.

34 John Gillespie, "Transplanting Commercial Law Reform: Developing a Rule of Law in Vietnam" diajukan sebagai PhD. Thesis di Australian National University, 2005, hlm. 99-100.

35 Carlye A. Thayer, "Vietnam and the Challenge of Political Civil Society," Contemporary Southeast Asia 31, No. 1, 2009, hlm. 1-27. 
sendiri. ${ }^{36}$ Namun, pertimbangan tambahan juga selalu hadir. Kepemimpinan Vietnam tampaknya bersatu dalam komitmen untuk memelihara stabilitas politik dalam negeri dan kadang-kadang membatasi kemunculan pluralisme. Hukum memainkan peran penting dalam kedua kecenderungan ini; telah diminta untuk membawa pluralisme yang lebih besar ke masyarakat Vietnam dan untuk menahan ketidakstabilan politik yang dapat dihasilkan oleh pluralisme. Dengan demikian, kebijakan Doi Moi dan proses paralel atas reformasi politik telah menghadirkan tantangan yang intens kepada komunitas hukum Vietnam. ${ }^{37}$

Sistem pengadilan sebelum 1992 diselenggarakan terutama di tingkat lokal di sekitar konsep unit administrasi, daripada memiliki sistem nasional pengadilan dan jaksa yang terintegrasi secara vertikal. Selama periode ekonomi terpusat, hukum dan aturan hukum diabaikan, pemujaan terhadap rencana lima tahun dan birokrasi menjadi sewenang-wenang. Akibatnya, pengadilan sangat terdesentralisasi pada tingkat administrasi dan produktivitas menuju ke titik terendah. Dalam praktiknya, para hakim dan pengadilan sebelum dimulainya reformasi ekonomi sangat parokial, terutama berfokus pada menjaga hubungan baik dengan kader Partai lokal, menyebabkan kualitas putusan hakim dipertanyakan. Struktur birokrasi yang dibuat berdasarkan perencanaan terpusat mendorong kesewenang-wenangan dan meninggalkan keterbukaan informasi. Ketika Vietnam memulai program reformasi ekonomi yang berorientasi pasar pada 1986, kekurangan sistem hukum sosialisnya menjadi sangat jelas. Di mana, sebelumnya, sistem hukum parokial dan politik tampak tepat, dalam ekonomi pasar, strategi organisasi seperti itu mulai terlihat semakin seperti penghalang bagi pertumbuhan dan investasi.

Reformasi 1992 berjalan lambat untuk memperkuat pengadilan di tingkat lokal, tetapi masih menyisakan sebagian besar kendali atas pengoperasian sistem pengadilan di tangan para pejabat lokal. Sifat desentralisasi yang terus menerus dari pengadilan memperkuat pengaruh pemerintah daerah terhadap peradilan,

\footnotetext{
36 Pamela Cox, "Juvenile Justice Reform and Policy Convergence in the New Vietnam," Youth Justice 10, No. 3, 2010, hlm. 227-44.

${ }^{37}$ Lihat, Adam Fforde, Vietnamese State Industry and the Political Economy of Commercial Renaissance, Chandos Publishing, Oxford, 2007.
} 
sehingga melanggengkan beberapa aspek parokial negatif yang ingin dihapus melalui reformasi 1992.

Setelah reformasi 1992, pemerintah daerah memertahankan otoritas atas anggaran pengadilan yang memiliki kompetensi relatif dalam satuan pemerintahan daerah. Hakim dan personil pengadilan tetap secara finansial tergantung langsung pada pejabat vertikal Kementerian Kehakiman. Ketergantungan finansial ini, tidak diragukan lagi, menghasilkan peningkatan pengaruh terhadap operasi pengadilan dan hasil dari kasus-kasus tertentu yang menarik. Sementara reorganisasi pengadilan pada 1992 dimaksudkan untuk memusatkan wewenang pusat atas pengadilan provinsi dan lokal, garis pemisah yang kabur antara pemerintah daerah dan peradilan memastikan bahwa pemerintah daerah akan tetap memegang kendali atas aspek prosedural maupun substantif pengadilan.

Berbagai gejolak perubahan ini, walaupun tentu menguntungkan dalam jangka pendek sebagai akibat responsivitas pemerintah, tetapi menimbulkan persoalan sehubungan tuntutan sistem hukum yang stabil, prediktif, dan dapat ditegakkan. Peminjaman sistem hukum dari aneka yurisdiksi dan sumber berlangsung cepat, mengingat kondisi dan kapasitas badan pembentuk undangundang waktu itu yang belum berpengalaman. Juga, kapasitas anggota legislatif yang tak terbiasa dengan teori hukum baru menghasilkan produk undangundang yang tidak sinkron, tidak koheren, dan tidak logis. ${ }^{38}$ Selain itu, reformasi yang tidak lengkap mengungkapkan kelemahan sistem hukum yang hanya bergantung pada hukum yang berlaku dan mengecualikan sumber hukum lainnya. ${ }^{39}$ Kelemahan-kelemahan ini terutama: (i) inkoherensi dan konflik antara hukum tertulis atau ketidakjelasan makna, yang menyebabkan banyak kesulitan dalam implementasi; (ii) undang-undang tidak dapat memberikan solusi untuk semua kasus; dan (iii) undang-undang dengan cepat menjadi usang. ${ }^{40}$

Untuk memecahkan masalah pertama, interpretasi hukum terhadap undang-undang diperlukan, sedangkan kelemahan kedua dan ketiga dapat

\footnotetext{
${ }^{38}$ Maria Paula Reyes, The Challenges of Legal Transplants in a Globalized Context, Saarbrücken, Germany: LAP Lambert Academic Publishing, 2017.

${ }^{39}$ Paul Schiff Berman, Global Legal Pluralism : A Jurisprudence of Law beyond Borders, Cambridge: Cambridge University Press, 2014.

${ }^{40}$ Eric A. Posner, The Perils of Global Legalism, Chicago, IL: The University of Chicago Press, 2010.
} 
diatasi dengan kreativitas dan fleksibilitas dalam penerapan hukum. Dalam konteks ini, tidak mengherankan jika yurisprudensi muncul kembali sebagai salah satu solusi yang paling cocok untuk menyelesaikan masalah-masalah efektif, membantu hakim dan arbiter dalam menyelesaikan perselisihan secara lebih adil dan, secara khusus, membuat sistem hukum lebih stabil, dapat diprediksi, dan dapat ditegakkan.

Meskipun mungkin ada peningkatan independensi dari pemerintah daerah, tidak ada indikasi bahwa pengadilan akan menjadi independen dari otoritas pusat sebagai hasil dari reformasi saat ini. Di sini, "otoritas pusat" tidak merujuk pada pemerintah pusat, tetapi pada pengaruh organisasi Partai Komunis terhadap aktivitas pengadilan dan aparatur pengadilan. Ketika ada kebijakan untuk mengisolasi pengadilan dari pengaruh pemerintah daerah, reformasi barubaru ini tidak melakukan apa pun untuk melindungi pengadilan dari pengaruh otoritas Partai Komunis di tingkat pusat. Hasil ini kemungkinan berdasarkan desain, bukan sesuatu yang tanpa sengaja. Reformasi proses hukum yang sedang dilakukan Vietnam saat ini pasti akan membawa ke titik di mana akan ada kontradiksi yang semakin terbuka di antara sistem yang bersaing. Di satu sisi, proses reformasi memperkuat profesionalisme dan kemandirian aktor dalam sistem hukum, dan di sisi lain, sistem peradilan harus terlepas dari sistem politik. ${ }^{41}$

\section{Yurisprudensi dalam Vietnam Kontemporer}

Meskipun diperlukan, pengakuan yurisprudensi di Vietnam berlangsung sangat terlambat, setelah terjadi reformasi hukum. Ini karena saat menjalankan sistem hukum sosialis, hakim tidak memiliki fungsi dan kekuasaan untuk menafsirkan undang-undang. Pandangan ini tampaknya serupa dengan pandangan di Eropa pada abad ke-19, tetapi tidak didasarkan atas alasan pemisahan kekuasaan yang ketat. Dalam sistem hukum sosialis, alih-alih bebas melakukan semua yang tidak dilarang oleh hukum, tiap subjek hanya dapat melakukan apa yang diizinkan oleh hukum. Akibatnya, undang-undang

41 Adam Fforde dan Lada Homutova, "Political Authority in Vietnam: Is The Vietnamese Communist Party a Paper Leviathan?," Journal of Current Southeast Asian Affairs 364, No. 3, 2017, hlm. 91-118. 
dianggap sebagai sumber hukum resmi, dan satu-satunya sumber hukum yang mengatur kehidupan sosial, yang harus diumumkan dan diinterpretasikan oleh legislatif, sementara hakim hanya berkewajiban menerapkan hukum. ${ }^{42}$

Selain itu, tuntutan tinggi untuk disiplin dalam sistem hukum sosialis tidak memungkinkan penciptaan dan pengembangan hukum dalam bentuk kebijaksanaan hakim. Manakala kesulitan dalam menyelesaikan kasus tertentu, terutama jika undang-undang tidak cukup jelas, pengadilan yang lebih rendah harus meminta pendapat pengadilan di atasnya; jika pengadilan tinggi yang kompeten tidak menentukan alasan hukum dalam undang-undang untuk menyelesaikan masalah ini, pengadilan akan memiliki hak, dan kewajiban, untuk menolak memeriksa dan memutus perkara. ${ }^{43}$

Alih-alih menangani masalah utama, di Vietnam, beberapa solusi telah diluncurkan untuk membantu mengisi celah dan kekosongan undang-undang, seperti ringkasan-ringkasan kasus hukum yang dihimpun oleh Partai Komunis. Dalam bentuk seperti itu, seperti resolusi, pengiriman, laporan, kesimpulan, surat resmi, dan sebagainya, hal tersebut memberikan solusi praktis dan lebih tepat untuk memastikan kesatuan kegiatan peradilan dan menjadi norma yang tidak mengikat kepada para hakim. Namun, pendekatan ini tidak mungkin efektif dalam meningkatkan kapasitas pengadilan. Itu hanya menyelesaikan sebagian masalah dan tidak bisa mengimbangi ketimpangan hukum yang berlaku. Catatan-catatan yang dihimpun partai tak dilengkapi analisis dan komentar hukum untuk setiap kasus spesifik. Sebagai akibatnya, himpunan catatan itu tidak bermanfaat dan tak dapat digunakan untuk kasus-kasus yang terjadi pada masa yang akan datang. Di atas semua itu, himpunan catatan itu sendiri bukan yurisprudensi dalam arti sebenarnya. Meskipun beberapa bagian dari himpunan itu diresmikan dalam Surat Edaran Ketua Mahkamah Agung dan juga menjadi pertimbangan hakim dalam memutus perkara, tetapi tindakan-tindakan itu sebetulnya dilakukan atas dasar delegasi undang-undang. ${ }^{44}$

\footnotetext{
${ }^{42}$ Louis M. Holscher, "Recent Legal and Political Changes in Vietnam and the Role of the Courts in the Vietnamese Criminal Justice System," International Criminal Justice Review 6, No. 1, 1996, 58-78.

${ }^{43}$ Ibid...

44 Nguyen Hung Quang, "Vietnamese Court Reform: constancy and change in the contemporary period," Paper konferensi dipresentasikan pada Mapping Vietnam's Legal Culture, University of Victoria, Canada, 2003.
} 
Pada akhirnya, lewat resolusi Kongres Partai Komunis pada 2005, terdapat perintah untuk mengembangkan yurisprudensi dalam sistem hukum Vietnam. Dalam resolusi ini, yurisprudensi dianggap sebagai solusi yang diperlukan untuk melaksanakan misi mengatasi ketimpangan hukum tertulis, menciptakan stabilitas, dan mewujudkan transparansi pemeriksaan perkara. Upaya pengembangan yurisprudensi itu akan dibantu oleh Partai Komunis, lembaga negara yang bergengsi, berpengalaman, dan memiliki kader-kader hakim yang prestisius. 45

Sayangnya, resolusi partai itu harus menunggu selama sepuluh tahun untuk dapat dijalankan dengan efektif. Inti pelaksanaan baru dimulai sejak 2012, ketika ada perintah kepada Mahkamah Agung untuk membangun yurisprudensi, sebuah langkah awal pengakuan makna penting salah satu sumber hukum ini. Kemudian, sebuah konstitusi baru disusun dan diberlakukan pada 2013 dan sebuah kodifikasi hukum perdata disahkan pada 2015.

Konstitusi 2013 memberdayakan lembaga perwakilan dalam rangka pembentukan undang-undang sebagaimana dimaksud dalam Pasal 69.46 Sementara itu, Pasal 102 mengamanatkan Mahkamah Agung untuk melindungi dan menegakkan keadilan. ${ }^{47}$ Ketentuan ini dianggap penting karena menjadi dasar pengembangan yurisprudensi. Dalam tahap selanjutnya, Undang-Undang Mahkamah Agung disahkan pada 2014, yang antara lain memberikan perintah kepada hakim agung untuk mengembangkan yurisprudensi. Perlu dicatat bahwa dalam tahap berikutnya, pada 2015, diundangkan juga Kitab Undang-Undang Hukum Acara Perdata dan Kitab Undang-Undang Hukum Acara Peradilan Tata Usaha Negara. Sejak saat itu, yurisprudensi secara resmi telah dibangkitkan kembali dan menjadi bagian dari sistem hukum nasional, dengan asumsi

45 Lihat, Pip Nicholson, "Vietnamese legal institutions in comparative perspective: contemporary constitutions and courts considered," dalam K. Jayasuriya (ed.), Law, Capitalism and Power in Asia, Routledge, London, 1999.

46 Untuk lebih jelas, berikut dikutipkan bunyi ketentuan Pasal 69 sebagai berikut: The National Assembly is the bighest representative body of the People and the highest body of State power of the Socialist Republic of Vietnam. The National Assembly exercises constitutional and legislative powers, decides significant national affairs and exercises supreme control over all activities of the State.

47 Untuk lebih jelas, berikut dikutipkan bunyi ketentuan Pasal 102 sebagai berikut: (1) The People's Courts are the judicial bodies of the Socialist Republic of Vietnam, exercising the judicial power; (2) The People's Courts comprise the Supreme People's Court and other courts established by law; (3) The People's Courts are responsible for the protection of justice, human rights, citizen's rights, socialist regime, interests of the State and legal rights and interests of organisations and individuals. 
perannya sebagai sumber hukum. Tetapi ini hanyalah awal dari masalah yang jauh lebih kompleks dan tidak pasti yang melibatkan peran, sifat, formalitas, dan analisis sumber hukum ini di Vietnam kontemporer. Pada 2016, sebanyak enam putusan pengadilan dibukukan, dan sejak 2019, sebuah laman resmi diluncurkan untuk memuat himpunan yurisprudensi itu.

Tidak diragukan lagi bahwa pengakuan terhadap yurisprudensi menunjukkan tanda positif dalam komitmen pemerintah untuk memastikan penerapan hukum yang seragam dalam persidangan, dan memastikan konsistensi, transparansi, dan kepastian putusan pengadilan. Namun, masih ada pertanyaan mengenai efektivitas jangka panjang, yang menurut penulis membutukan model pilihan yurisprudensi yang paling sesuai. Di satu sisi, sejak diluncurkannya kebijakan Doi Moi pada di Vietnam 1986, dengan reformasi rezim ekonomi (dari ekonomi terencana-terpusat ke ekonomi pasar), tugas mempelajari dan meminjam hukum asing, yang dianggap sebagai transplantasi hukum, semakin penting untuk memenuhi persyaratan reformasi dalam sistem hukum sosialis negara yang ada. Dipercayai bahwa karena yursiprudensi telah sangat dikembangkan oleh sistem hukum utama lainnya dalam common law dan sistem kontinental, transplantasi yurisprudensi ke Vietnam dapat menjadi cara yang efektif untuk membangun model preseden bagi negara ini.

Meskipun yurisprudensi adalah teknik yang telah digunakan di hampir setiap sistem hukum di dunia, pada kenyataannya, masing-masing negara harus membangun model sendiri sehubungan dengan perbedaan dalam lingkungan dan perkembangan sosial-politik. Dengan demikian, pertanyaan yang mengemuka bukanlah "apakah harus menerima yurisprudensi", akan tetapi model yurisprudensi yang paling sesuai. Hal ini karena dalam Vietnam kontemporer, lingkungan dan sosial politik sudah beranjak jauh, tidak seperti di masa lampau, apalagi ketika di bawah naungan rezim komunis secara ketat.

Sistem hukum Vietnam pada masa lalu didasarkan pada ide-ide kaku teori hukum sosialis, di mana yursiprudensi tidak diakui sebagai sumber hukum. Oleh karena itu, Vietnam tidak memiliki pemahaman praktis dan ilmiah tentang makna dan fungsi yurisprudensi dalam sistem hukum. Oleh karena itu, penting bagi legislator Vietnam untuk mencari sistem hukum lain yang telah 
menggunakan yurisprudensi, apakah sebagai sumber hukum atau sebagai sarana untuk menafsirkan hukum, serta apakah yurisprudensi memiliki otoritas yang mengikat atau, untuk tujuan transplantasi ke dalam kegiatan peradilan. 48

Perbedaan paling penting antara model yurisprudensi di Vietnam dan negara-negara lain adalah bahwa yurisprudensi Vietnam, secara alami, tidak terdiri dari putusan pengadilan (atau lebih tepatnya, pertimbangan hukum yang diajukan oleh para hakim yang mengadili kasus), tetapi sebaliknya terdiri dari himpunan pendapat panel hakim agung di Mahkamah Agung, yang memeriksa dan mencatat putusan-putusan pengadilan, terutama putusan pengadilan tertinggi yang dikendalikan oleh Partai Komunis, supaya diikuti oleh pengadilanpengadilan lain. ${ }^{49}$ Model seperti ini tidak ditemukan dalam sistem hukum arus utama. Di negara Anglo-Saxon, yurisprudensi adalah putusan hakim itu sendiri. Di negara kontinental, yurisprudensi merupakan pendapat hakim yang merujuk kepada putusan pengadilan yang dilakukan mandiri dan tidak oleh pihak ketiga. 50

Salah satu alasan yang diajukan oleh para pembuat undang-undang Vietnam untuk menjelaskan keberadaan proses ini adalah rendahnya kualitas penilaian dan kemampuan profesional para hakim. Bahkan, pemerintah Vietnam mengakui kelemahan hakim menjalankan persidangan yang gagal memenuhi persyaratan. Menurut statistik Partai Komunis, selama sepuluh tahun mulai dari 2000 hingga 2010, tingkat putusan tingkat pertama yang direvisi, dibatalkan, atau diperiksa ulang dalam kasus hukum sipil dan keluarga meningkat dari 82,6\% menjadi 90,7\%, karena jumlah putusan tingkat pertama meningkat luar biasa. ${ }^{51}$ Ini sebagian mencerminkan fakta bahwa kualitas putusan tingkat pertama, dan karenanya para hakim, tidak memenuhi harapan masyarakat. Banyak upaya telah dilakukan untuk meningkatkan kualitas penilaian, seperti memberikan panduan

\footnotetext{
48 Pip Nicholson, "Judicial independence and the rule of law: the Vietnam court experience," Australian Journal of Asian Law 3, No. 1, 2001, hlm. 37-58.

${ }^{49}$ Pip Nicholson dan Nguyen Huang Quang, "The Vietnamese judiciary: the politics of appointment and promotion," Pacific Rim Law \& Policy Journal Association 14, No. 1, 2005, 1-34.

${ }^{50}$ Ibid

${ }^{51}$ Lihat, John Gillespie dan Albert H. y. Chen, Legal Reforms in China and Vietnam : A Comparison of Asian Communist Regimes, Taylor \& Francis Ltd, London, 2010.
} 
terperinci tentang struktur putusan dan cara menulis putusan. Masalah struktur penilaian telah ditentukan oleh Partai Komunis dalam memandu dokumen. ${ }^{52}$

Salah satu perbedaan paling penting yurisprudensi antara hukum sipil dan tradisi Anglo-Saxon adalah alasan hukum. ${ }^{53}$ Sementara para ahli hukum Eropa kontinental menciptakan prinsip-prinsip umum dalam hukum tertulis untuk mengadili kasus-kasus tertentu melalui metode deduktif, tradisi Anglo-Saxon lebih memilih metode induktif, yang berasal dari kasus yang sama untuk mencapai solusi terpadu bagi para hakim dalam proses persidangan. Terlepas dari perbedaannya, kedua tradisi menekankan peran argumen, atau pertimbangan hakim dalam putusan mereka, yang merupakan bagian paling penting dari yurisprudensi. Oleh karena itu, ketika putusan pengadilan di Vietnam sendiri tidak mengandung argumen yang memadai, preseden tidak memiliki pengaruh kuat untuk membujuk hakim yang lebih rendah untuk mengikuti jalan itu.

Sistem hukum Vietnam telah mengalami banyak pengaruh negatif karena pendekatan ini, yang jika tidak segera diselesaikan, dapat mengakibatkan konsekuensi yang lebih serius minimal karena tiga hal. Pertama, para sarjana prihatin tentang kurangnya fleksibilitas model yurisprudensi yang membutuhkan kepatuhan dengan prosedur administrasi, suatu karakteristik yang tidak dapat ditemukan di negara lain. Kedua, ada keraguan mengenai kapasitas dan independensi sistem peradilan, terutama para hakim. Bersama dengan kurangnya interpretasi hukum dalam putusan, kekurangan sistem peradilan dapat menyebabkan model yurisprudensi saat ini gagal mencapai tujuannya. Ketiga, meskipun yurisprudensi saat ini dianggap sebagai sumber hukum, legislator belum menemukan pendekatan yang lebih cocok untuk menyesuaikannya dengan sistem hukum Vietnam saat ini. Kekurangan ini berfungsi sebagai dasar untuk memberikan solusi dan rekomendasi untuk pendekatan transplantasi hukum campuran yang lebih baik pada masa depan.

\footnotetext{
${ }^{52}$ Lihat, J. London, Politics in Contemporary Vietnam : Party, State, and Authority Relations, Palgrave MacMillan, Basingstoke, 2014.

${ }^{53}$ Lihat, Raymond Wacks, Understanding Jurisprudence: An Introduction to Legal Theory, Oxford University Press, Oxford, 2017.
} 
Transplantasi hukum campuran, sebagai solusi untuk pengembangan hukum, memiliki kelebihan dan kelemahannya sendiri. Salah satu keuntungan adalah bahwa transplantasi ini menjamin efektivitas solusi hukum baru yang berasal dari sistem hukum yang berbeda. Namun, karena kurangnya teknik hukum dan pelepasan solusi hukum dari konteks seperti karakteristik yang lebih luas dari sistem hukum dan kondisi kelembagaan, transplantasi hukum campuran dapat mengakibatkan konflik bagi sistem hukum penerima. ${ }^{54}$ Tanpa harmonisasi yang mendalam antara aturan yang ditransplantasikan dan faktorfaktor fundamental dari sistem penerima, transplantasi hukum campuran hanya bisa menjadi solusi sementara dan bersifat jangka pendek. Harus diingat bahwa transplantasi hukum campuran terjadi dalam konteks pilihan bebas atau penerimaan sukarela. 55

Hal ini membantu untuk menginformasikan pengembangan pendekatan transplantasi hukum campuran yang bisa diterapkan. Dalam konteks artikel ini, hal pertama dan terpenting yang perlu dilakukan saat ini adalah mengembangkan doktrin hukum yang tepat bagi proses transplantasi hukum. Sejarah sistem hukum Vietnam, sebagaimana disajikan di atas, menunjukkan bahwa teori hukum sipil memainkan peran penting dalam yurisprudensi dan jejaknya tetap bertahan hingga saat ini. Sebagai bagian dari teori, konsep sumber hukum tambahan akan diperlukan untuk mengidentifikasi sifat sumber hukum di Vietnam, termasuk yurisprudensi, untuk memastikan stabilitas hukum.

\section{Penutup}

Transplantasi hukum tidak identik begitu saja dengan peminjaman atau importasi sebuah sistem hukum asing ke dalam sistem hukum nasional sebuah negara. Namun demikian, tranplantasi adalah metode yang bermanfaat dalam jangka panjang sebagai solusi pembaruan hukum akibat penyingkiran hukum lama yang dianggap tidak lagi sesuai dengan perkembangan keadaan. Dalam pengalaman Vietnam, hal penting yang perlu diperhatikan mencakup tiga hal

${ }^{54}$ Lihat, Vito Breda, Legal Transplants in East Asia and Oceania, Cambridge University Pres, Cambridge, 2019.

55 Lihat, Xiaobing Li, Modern Chinese Legal Reform: New Perspectives, The University Press of Kentucky, Lexington, 2017. 
sebagai berikut. Pertama, transplantasi hukum pada akhirnya harus bersifat campuran, dalam arti tidak bisa mengabaikan jejak hukum dalam ruang dan waktu setempat. Kedua, transplantasi hukum membutuhkan kapasitas pemilihan dan pemilahan prinsip dan konsep hukum dalam formulasi undang-undang baru bagi para legislator, sembari meningkatkan kapasitas pengadilan dan para hakim. Ketiga, transplantasi hukum tidak dapat dipaksakan, akan tetapi harus bersifat sukarela, diikuti kemampuan membangun sumber daya pendukung yang menjamin stabilitas, prediktibalitas, dan penegakan sistem hukum. Ketiga hal tersebut dapat dijumpai dalam negara yang melakukan transplantasi dengan permasalahan yang identik dengan Vietnam.

\section{Daftar Pustaka}

\section{Buku}

Berman, Paul Schiff, Global Legal Pluralism : A Jurisprudence of Law beyond Borders, Cambridge University Press, Cambridge, 2014.

Breda, Vito, Legal Transplants in East Asia and Oceania, United Kingdom, Cambridge, Cambridge University Pres, 2019.

Bryant, Tannetje, dan Brad Jessup, "Fragmented Pragmatism: The Conclusion and Adoption of International Treaties in Vietnam." Dalam Asian Socialism and Legal Change: The dynamics of Vietnamese and Chinese Reform, disunting oleh john Gillespie dan Pip Nicholson, ANU Press, Canberrra, 2005.

Dupré, Catherine, Importing the Law in Post-Communist Transitions: The Hungarian Constitutional Court and the Right to Human Dignity, Bloomsbury Publishing, London, 2003.

Fforde, Adam, Vietnamese State Industry and the Political Economy of Commercial Renaissance, Chandos Publishing, Oxford, 2007.

Gillespie, John, "Transplanting Commercial Law Reform: Developing a Rule of Law in Vietnam," 2005.

Gillespie, John, dan Albert H. y. Chen, Legal Reforms in China and Vietnam: A Comparison of Asian Communist Regimes, UK: Taylor \& Francis Ltd, London, 2010.

Gillespie, John, dan Pip Nicholson, ed., Law and Development and the Global Discourses of Legal Transfers, Cambridge University Press, London, 2012.

Gillespie, John Stanley, Transplanting Commercial Law Reform: Developing a 'Rule of Law' in Vietnam, London: Ashgate Publishing Ltd, London, 2006. 
Legrand, Pierre, "What Legal Transplant?" Dalam Adopting Legal Cultures, disunting oleh David Nelken dan Johannes Feest, Hart Publishing, London, 2001.

Li, Xiaobing, Modern Chinese Legal Reform: New Perspectives, United States: The University Press of Kentucky, Lexington, 2017.

London, J., Politics in Contemporary Vietnam: Party, State, and Authority Relations, United Kingdom: Palgrave MacMillan, Basingstoke, 2014.

Ng, Michael H.K., Legal Transplantation in Early Twentieth-Century China: Practicing Law in Republican Beijing (1910s-1930s), Routledge, London, 2014.

Nghia, Pham Duy, "Confucianism and the Conception of the Law in Vietnam." Dalam Asian Socialism and Legal Change: The Dynamics of Vietnamese and Chinese Reform, disunting oleh John Gillespie dan Pip Nicholson. Canberrra, Asia Pasific Press, 2005.

Nicholson, Pip, "Vietnamese legal institutions in comparative perspective: contemporary constitutions and courts considered." Dalam Law, Capitalism and Power in Asia, disunting oleh K. Jayasuriya, Routledge, London, 1999.

Posner, Eric A., The Perils of Global Legalism, IL: The University of Chicago Press, , Chicago, 2010.

Reyes, Maria Paula, The Challenges of Legal Transplants in a Globalized Context, Saarbrücken, LAP Lambert Academic Publishing, Germany, 2017.

Wacks, Raymond, Understanding Jurisprudence: An Introduction to Legal Theory, United Kingdom: Oxford University Press, Oxford, 2017.

Watson, Alan, Legal Transplants: An Approach to Comparative Law, GA: University of Georgia Press, Athens, 1993.

\section{Jurnal}

Birgerson, Susanne, "The Evolution of Soviet Foreign Policy in Southeast Asia: Implications for Russian Foreign Policy." Asian Affairs: An American Review 23, No. 4 (1997).

Chau, Giang, "Trade to Firm up After Solid Promotion During First Year." Vietnam Investment Review 10, No. 1 (2003).

Cima, Ronald J., “Vietnam's Economic Reform: Approaching the 1990s." Asian Survey 29, No. 5, 1989.

Conceição, Pedro, dan Ronald U. Mendoza, "Anatomy of the Global Food Crisis." Third World Quarterly 30, No. 6, 2009.

Cox, Pamela, "Juvenile Justice Reform and Policy Convergence in the New Vietnam." Youth Justice 10, No. 3, 2010. 
Duc, Pham Van, dan Tran Tuan Phong, "The Views of Some Economic Theories on the Economic Crisis of Capitalism and Some Lessons for Vietnam." World Review of Political Economy 1, No. 4, 2010.

Fforde, Adam, dan Lada Homutova, "Political Authority in Vietnam: Is The Vietnamese Communist Party a Paper Leviathan?" Journal of Current Southeast Asian Affairs 364, No. 3, 2017.

Foster, Frances H., "American Trust Law in a Chinese Mirror", Minnesota Law Review 94, 2010.

Hai, Bui Xuan, dan Chihiro Nunoi, "Corporate Governance in Vietnam - A System in Transition." Hitotsubashi Journal of Commerce and Management 42, 2008.

Hiep, Le Hong, “Vietnam's Strategic Trajectory: From Internal Development to External Engagement", Australian Strategic Policy Institute, Canberra, 2012.

Hoan, Buu, "Soviet Economic Aid to Vietnam." Contemporary Southeast Asia 12, No. 4, 1991.

Hoang, N., A.Toppinen, dan K. Lahtinen, "Foreign subsidiary development in the context of a global recession: a case of the furniture industry in Vietnam." The International Forestry Review 17, No. 4, 2015.

Holscher, Louis M., "Recent Legal and Political Changes in Vietnam and the Role of the Courts in the Vietnamese Criminal Justice System." International Criminal Justice Review 6, No. 1, 1996.

Khuong, Vu Minh, “Can Vietnam Achieve More Robust Economic Growth? Insights from a Comparative Analysis of Economic Reforms in Vietnam and China." Journal of Southeast Asian Economies 321, No. 1, 2015.

Legrand, Pierre, "The Impossibility of 'Legal Transplants", Maastricht Journal of European and Comparative Law 4, 1997.

Minh, Pham Quang, "Teaching international relations in Vietnam: chances and challenges." International Relations of the Asia-Pacific 9, No. 1, 2009.

Nicholson, Pip, "Judicial independence and the rule of law: the Vietnam court experience." Australian Journal of Asian Law 3, No. 1, 2001.

, dan Nguyen Huang Quang. "The Vietnamese judiciary: the politics of appointment and promotion." Pacific Rim Law E Policy Journal Association 14, No. 1, 2005.

Rose, Carol V., “The 'New' Law and Development Movement in the Post-Cold War Era: A Vietnam Case Study." Law E Society Review 31, No. 1, 1998.

Sidel, Mark, "The Re-Emergence of Legal Discourse in Vietnam." The International and Comparative Law Quarterly 43, No. 1, 1994.

Teubner, Gunther, "Legal Irritants: Good Faith in British Law or How Unifying Law Ends up in New Divergences." Modern Law Review 61, 1998. 
Thayer, Carlye A., "Vietnam and the Challenge of Political Civil Society." Contemporary Southeast Asia 31, No. 1, 2009.

"Force Modernization: Vietnam." Southeast Asian Affairs, 2018.

Thuyet, Pham Van, "Vietnam's Legal Framework for Foreign Investment." The International Lawyer 33, No. 3, 1999.

Watson, Alon, "The Birth of Legal Transplants." Georgia Journal of International and Comparative Law 41, 2013.

Wood, Adrian, "Deceleration of inflation with acceleration of price reform: Vietnam's remarkable recent experience." Cambridge Journal of Economics 13, No. 4, 1989.

\section{Disertasi}

Quang, Nguyen Hung, "Vietnamese Court Reform: constancy and change in the contemporary period", University of Victoria, Canada, 2003. 